\title{
The Cystic Fibrosis of Exocrine Pancreas
}

\author{
Michael Wilschanski ${ }^{1}$ and Ivana Novak ${ }^{2}$ \\ ${ }^{1}$ Pediatric Gastroenterology, Hadassah University Hospital, Jerusalem 91240, Israel \\ ${ }^{2}$ Molecular Integrative Physiology, Department of Biology, University of Copenhagen, DK 2100 \\ Copenhagen Ø, Denmark \\ Correspondence: inovak@bio.ku.dk
}

\begin{abstract}
The cystic fibrosis transmembrane conductance regulator (CFTR) protein is highly expressed in the pancreatic duct epithelia and permits anions and water to enter the ductal lumen. This results in an increased volume of alkaline fluid allowing the highly concentrated proteins secreted by the acinar cells to remain in a soluble state. This work will expound on the pathophysiology and pathology caused by the malfunctioning CFTR protein with special reference to ion transport and acid-base abnormalities both in humans and animal models. We will also discuss the relationship between cystic fibrosis (CF) and pancreatitis, and outline present and potential therapeutic approaches in CF treatment relevant to the pancreas.
\end{abstract}

$\mathrm{T}_{\mathrm{n}}^{\mathrm{h}}$ he pancreas is one of the organs earliest and most seriously affected by cystic fibrosis (CF). Although cystic fibrosis transmembrane conductance regulator (CFTR) is expressed only in a very small percentage of exocrine cells, its malfunction has catastrophic effects on the whole organ, resulting in its eventual destruction, leading to maldigestion and malnutrition. In recent years, new therapeutic approaches are being developed to improve anion/fluid balance, especially in the airways. Whether these will have any value for the pancreas requires a more detailed understanding of pancreatic function drawn from clinical and genetic studies and cell/organ studies of ion channels and transporters specific for pancreatic cells. In the present work, we try to raise some of the critical issues of the physiology and pathophysiology of the pancreas in CF.

\section{EXOCRINE PANCREATIC ABNORMALITIES}

\section{Exocrine Pancreatic Function}

The CFTR protein is highly expressed in pancreatic ductal epithelia and permits anions and fluid to enter the ductal lumen. There is evidence that CFTR is associated with bicarbonate transport directly or indirectly (see below). Indeed according to the Quinton hypothesis, it is the defect in bicarbonate transport that is the primary defect in CF leading to mucoviscidosis (Quinton 2008). The net result of ductal function is an increased volume of alkaline fluid, allowing the highly concentrated proteins secreted by the acinar cells to remain in a soluble state. Absent or reduced CFTR channel function impairs chloride and bicarbonate transport of the ducts, which results in reduced volume and hyperconcentration of macromolecules (Kopelman et al.

Editors: John R. Riordan, Richard C. Boucher, and Paul M. Quinton

Additional Perspectives on Cystic Fibrosis available at www.perspectivesinmedicine.org

Copyright (C) 2013 Cold Spring Harbor Laboratory Press; all rights reserved; doi: 10.1101/cshperspect.a009746

Cite this article as Cold Spring Harb Perspect Med 2013;3:a009746 
M. Wilschanski and I. Novak

$1985,1988)$. The consequences of mutations in the CFTR gene have been shown by pancreatic function studies that indicate that CF patients have a low flow of secretions with a high protein concentration, which presumably will precipitate in the duct lumina causing obstruction and damage (Fig. 1).

These changes in the CF pancreas begin in utero and after delivery the process of small duct obstruction leading to large duct obstruction continues. At birth, and for several months afterward, there is a release into the blood stream of proteins originating in the pancreas. An example of this is immune reactive trypsinogen (IRT) that forms the basis for the neonatal screening test for CF. Interestingly, with this wholesale destruction of the exocrine pancreas occurring, the infant is asymptomatic. The rea- son for this silent destruction is yet to be determined. Eventually, this process results in severe inflammation, obstruction of ducts by mucus and calcium containing debris, the destruction of acini, and generalized fibrosis. Contrary to popular belief that the pancreas is entirely nonfunctioning at birth, the high IRT does show that some exocrine pancreatic tissue is still present and this may have a bearing on possible small molecule therapies targeted at the remainder of the pancreas that may rescue enough tissue to preserve viability of the remaining pancreas.

One of the most remarkable observations is that genetic factors exquisitely influence the degree of pancreatic disease and its rate of progression. Large studies of CF patients resulted in their classification as pancreatic insufficient

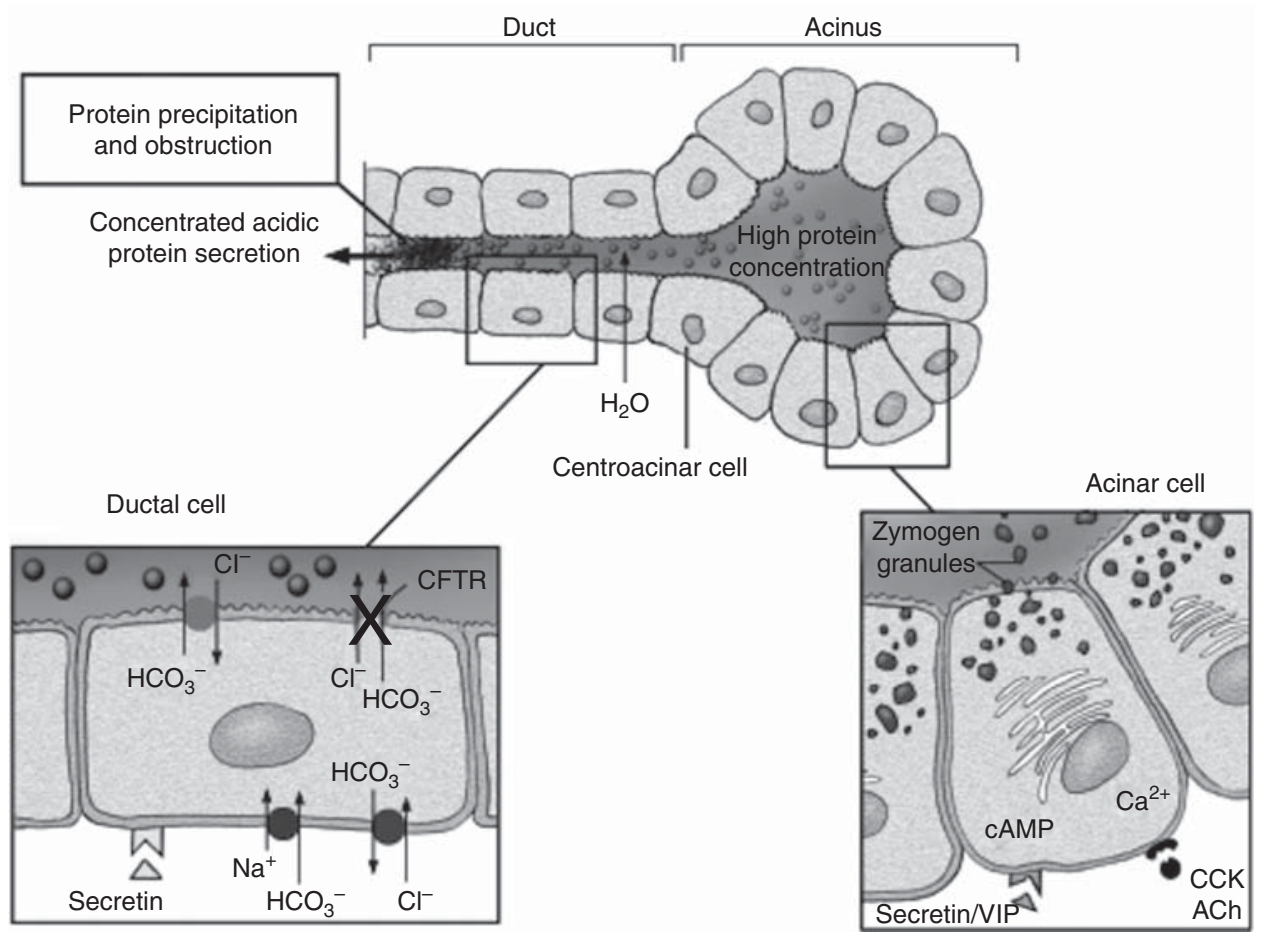

Figure 1. Pathogenesis of pancreatic disease in CF. Acinar cells secrete large quantities of protein, primarily in the form of digestive enzymes, into the acinar lumen. Under normal circumstances anions $\left(\mathrm{Cl}^{-}\right.$and $\left.\mathrm{HCO}_{3}{ }^{-}\right)$are secreted into the ductal lumen (see detailed model in Fig. 3). This provides a driving force for the movement of fluid into the lumen of the duct and maintains the solubility of secreted proteins in a dilute, alkaline solution. In CF, impaired anion transport into the proximal ducts results in decreased secretion of more acidic fluid, which leads to precipitation of secreted proteins. Intraluminal obstruction of the ducts then causes progressive pancreatic damage and atrophy. (From Wilschanski and Durie 2007; reprinted, with permission.) 
(PI) or pancreatic sufficient (PS). PI patients comprise $85 \%$ of all $\mathrm{CF}$ patients and have maldigestion as defined by evidence of steatorrhea following 72-hr fat balance studies. These PI patients require pancreatic enzyme replacement therapy with meals. In contrast, PS patients have evidence of pancreatic damage (these patients may be diagnosed by the high neonatal IRT test, which means that damage is occurring), but retain sufficient endogenous exocrine pancreatic function to sustain normal digestion.

Exocrine pancreatic status is directly linked to genotype (Kerem et al. 1990; Kristidis et al. 1992). Analysis of particular CFTR mutations in patients with these pancreatic phenotypes (PI vs. PS) revealed two categories of alleles: "severe" and "mild." Patients homozygous or compound heterozygous for severe alleles belonging to classes I, II, III, or VI confer pancreatic insufficiency, whereas a mild class IV or V allele sustains pancreatic function in a dominant fashion, even if the second mutation is severe. This observation appears plausible because all known mild alleles belong to class IV or $\mathrm{V}$, all of which are (or predicted to be) associated with some residual chloride channel activity at the epithelial apical membranes. However, this classification system is not entirely consistent as there are some class I mutations with the stop codon at the end of the gene that are in fact PS. A small proportion $(2 \%-3 \%)$ of patients carrying severe mutations on both alleles are PS at diagnosis, but most experience gradual transition from PS to PI. A few missense mutations (e.g., G85E) confer a variable pancreatic phenotype.

Although mild mutations confer sufficient CFTR function to prevent the pancreas from being completely destroyed, many PS patients have reduced exocrine pancreatic capacity and are associated with an increased risk of pancreatitis. Recurrent acute and chronic pancreatitis is a relatively infrequent complication of CF, first reported by Shwachman et al. (1975). In this retrospective study, only $0.5 \%$ of CF patients had pancreatitis. More recently, Durno et al. (2002) reported in a cohort of more than 1000 patients, followed over a period of 30 years, that the incidence was $1.7 \%$. All the patients with pancreatitis were PS. In fact, this subgroup of PS patients appears to be highly susceptible to pancreatitis because almost one in five was affected by this complication. There have been suggestions in the literature that PI patients may also have pancreatitis, but most probably in these patients pancreatic function was not fully investigated (De Boeck et al. 2005). In the largest study to date of CF PS patients, Ooi et al. (2011), in a seminal paper, determined the association between severity of CFTR genotype and the risk of pancreatitis. They examined a large cohort of 277 PS patients from two CF centers of which 62 had well-documented pancreatitis. Using a novel pancreatic insufficiency prevalence score, the mutations were divided into three main groups: severe, moderate-severe, and mild. They found that the proportion of patients who developed pancreatitis was significantly greater for genotypes in the mild group than the moderate-severe group. Thus, the more mild mutations are associated with increased risk of pancreatitis.

\section{Recurrent "Idiopathic" Pancreatitis}

Several studies have shown that patients with idiopathic acute, recurrent, and chronic pancreatitis carry a significantly higher frequency of CFTR gene mutations than the general population (Cohn et al. 1998; Sharer et al. 1998). Bishop et al. (2005) prospectively examined 56 patients with idiopathic recurrent acute or chronic pancreatitis by performing extensive genotyping and transepithelial measures of ion channel function and comparing the findings with healthy controls, obligate CF heterozygotes, and patients with a prior diagnosis of CF-disease (PS and PI phenotypes). Genetic analysis revealed that $24(40 \%)$ patients carried at least one CFTR mutation or variant, while six (10\%) carried alterations on both alleles.

The sweat chloride and nasal potential difference (NPD) results in the patients with pancreatitis ranged from the values for healthy controls and obligate heterozygotes to the values for CF patients with PS and PI. Median sweat chloride and NPD results in patients 
with none or one mutation were clustered with values obtained in controls and obligate heterozygotes. In contrast, in patients with pancreatitis carrying CFTR mutations on both alleles, median ion transport values were intermediate between those of the controls and obligate heterozygotes and those of CF PS patients. Some individual values overlapped with the $\mathrm{CF}$ patients, and the diagnosis of $\mathrm{CF}$ could be confirmed in $21 \%$ of patients by abnormal ion channel measurements. Thus, CFTR-mediated ion channel abnormalities are influenced by the number or severity of the CFTR mutations and show a range of abnormalities similar to those in patients with mild or severe classic $\mathrm{CF}$ at one extreme, and controls and obligate CF heterozygotes on the other. This continuum of electrophysiological abnormalities is not surprising as PS patients have a $17 \%$ risk of developing pancreatitis and many of these presentations are in adulthood.

Similar observations have been made in individuals with other CF-like phenotypes, such as men with infertility caused by congenital bilateral absence of the vas deferens who are known to carry a high frequency of CFTRgene mutations (Wilschanski et al. 2006). A relatively large population was examined, and similar to the patients with idiopathic pancreatitis, a wide range of electrophysiological abnormalities was observed. Abnormalities of CFTR function correlated closely with the number and severity of CFTR mutations.

In a recent publication, Schneider et al. (2011) investigated a large group of patients with "idiopathic" chronic pancreatitis and confirmed other studies that the combination of CFTR and serine protease inhibitor Kazaltype 1 (SPINK1) mutations markedly increase the risk of pancreatitis. However, a novel finding was that the variant R75Q of CFTR increases the risk of pancreatitis markedly. Patchclamp studies on cells expressing this mutation showed that bicarbonate current is significantly impaired. This mutation is not associated with CF but this CFTR variant may be a new class of mutation that is specific to the pancreas, particularly correlating with the electrophysiological studies.

\section{DUODENAL ACIDITY-PANCREAS AND OTHER ORGANS}

One of the hallmarks of CF in the digestive system is hyperacidity in the duodenum. Hyperacidity reflects multiorgan contributions. The low duodenal $\mathrm{pH}$ has most severe consequences for the activity of pancreatic enzymes and, in the long run, for the energy balance of a patient. The malfunctioning pancreas may further contribute to this acid/base imbalance.

\section{Problems with Pancreatic Enzymes but Not with Ulcers}

The acidic duodenal condition contributes to inactivation of pancreatic enzymes, if still present in PS patients, precipitation of bile acids, and the development of meconium ileus (Freedman et al. 2001). In PI patients, duodenal acidity limits the action of replacement enzymes, especially that of lipase. Decreased lipase activity causes steatorrhea and fat malabsorption that are difficult to treat (Robinson et al. 1990). In addition, there are increased circulating and tissue levels of (n-6) fatty acids and inflammatory mediators (leukotrienes B4, IL, TNF- $\alpha$ ), and there is oxidant stress and redox imbalance.

One would predict that the acidic duodenal environment would lead to ulcers. Paradoxically, it seems that CF patients do not have a higher incidence of duodenal ulcers (and even peptic ulcers may be diminished) (Kaunitz and Akiba 2006). Possibly, cellular pH buffering is elevated, as $\mathrm{HCO}_{3}^{-}$is trapped because of dysfunctional CFTR and down-regulated $\mathrm{Cl}^{-} / \mathrm{HCO}_{3}{ }^{-}$ exchangers. For example, in $\Delta$ F508 human or mouse models, pancreatic duct cells and enterocytes have higher resting intracellular $\mathrm{pH}$ (Elgavish 1991; Hirokawa et al. 2004). In addition, although $\mathrm{HCO}_{3}{ }^{-}$secretion is reduced, the duodenal acid/base barrier is only slightly impaired (Hirokawa et al. 2004).

\section{How Does Hyperacidity Arise?}

In CF patients, duodenal hyperacidity (below $\mathrm{pH} 4$ ) is prominent in the postprandial period; however, resting gastric and duodenal $\mathrm{pH}$ values 
are normal (Robinson et al. 1990; Barraclough and Taylor 1996).

At first, duodenal hyperacidity was thought to be caused by gastric hypersecretion (Cox et al. 1982). Therefore, to lower the acid load to duodenum, gastric acid production is curbed by use of proton pump inhibitors and $\mathrm{H}_{2}$ receptor antagonists. Indeed, omeprazole treatment seemed to improve fat digestion/absorption and improved patient weight (Barraclough and Taylor, 1996; Proesmans and De Boeck, 2003). Also in a recent successful model of CF, the ferret CFTR knockout, it was shown that omeprazole and ursodeoxycholic acid improved weight and survival of animals (Sun et al. 2010). Nevertheless, it seems that CFTR is also one of the $\mathrm{Cl}^{-}$channels or transporters that is necessary for gastric acid secretion (Heitzmann and Warth, 2007; Kopic and Geibel 2010). For example, the $\Delta$ F508 mutation in mice leads to decreased acid secretion (Sidani et al. 2007). As discussed in a review (Heitzmann and Warth 2007), it seems that the effect of CFTR on acid secretion may depend on the particular CFTR mutation and rescue by other $\mathrm{Cl}^{-}$transporters/channels.

Normally, acid chyme is neutralized by $\mathrm{HCO}_{3}{ }^{-}$secreted by duodenal epithelia, pancreatic duct and bile duct secretions (Ainsworth et al. 1991). Therefore, duodenal hyperacidity in CF has been ascribed to loss-of-function in the CFTR transporter, especially in duodenal and pancreatic epithelia.

\section{Pancreas-Lack of Bicarbonate Secretion and Other Effects}

One may ask whether, in CF, lack of pancreatic $\mathrm{HCO}_{3}{ }^{-}$secretion contributes to duodenal acidification and whether acidity, in turn, has consequences for overall pancreatic function. Here, we will deal with $\mathrm{pH}$-related effects on acini and whole pancreas function. $\mathrm{H}^{+} / \mathrm{HCO}_{3}{ }^{-}$transport in pancreatic ducts will be discussed in the next section.

Secretion originating from healthy acini (e.g., stimulated with cholecystokinin) is neutral or even alkaline in $\mathrm{pH}$, and contains enzymes (Sewell and Young 1975; You et al. 1983; Case and Argent 1993). In the pancreas with impaired duct function, secretion is not only low in volume and high in enzyme concentration, but it also has a relatively low $\mathrm{pH}$. For example, $\mathrm{CFTR}^{-/-}\left(\mathrm{CFTR}^{\mathrm{tm} 1 \mathrm{UNC}}\right)$ mouse pancreatic-biliary juice after secretin stimulation was four-fold lower in volume and had pH 6.6 compared with $\mathrm{pH} 8.1$ in wild-type mice (Freedman et al. 2001). In the $\mathrm{CFTR}^{-/-}$pig, pancreatic juice also had pH 5.7 compared with pH 8.4 in wild-type pigs (Uc et al. 2011). In addition, acidification of ductal and acinar lumens $\left(\mathrm{CFTR}^{-/-}\right.$ mice) can lead to secondary impairment of apical trafficking of zymogen granule membranes and solubilization of secretory (pro)enzymes (Freedman et al. 2001). Nevertheless, recent data on isolated acini of normal mice show that luminal/extracellular space is acidic, presumably owing to acidic secretory granules that contain the vacuolar type $\mathrm{H}^{+}$pump (Behrendorffet al. 2010). Taken together, it seems that optimal enzyme secretion processes relies on neutralizing fluid secretion of adjacent ducts and/or normal fluid secretion of acini.

In addition to the role of the pancreas in the duodenal $\mathrm{pH} /$ enzyme environment, duodenal hyperacidity has also indirect effects on pancreas. Increased release of gut hormones, such as secretin, results in increased signaling to the exocrine pancreas that would upregulate pancreatic $\mathrm{HCO}_{3}{ }^{-}$secretion. Indeed, in $\mathrm{CF}$ patients, increased plasma secretin levels are detected (Windstetter et al. 1997). In agreement, one study on $\mathrm{CFTR}^{-/-}$mice shows that mRNA for secretin (in duodenum) and vasoactive intestinal peptide (VIP) (in pancreas) were significantly increased, as well as pancreatic cAMP levels (De Lisle et al. 2001). Another study shows that such a situation may lead also to added stress, as indicated by increased expression of stress-/inflammation-related genes (Kaur et al. 2004). When the duodenal $\mathrm{pH}$ was experimentally corrected, expression of stress genes was also corrected.

Pancreatic dysfunction in CF involves the defective coupling of both ductal and acinar functions in the exocrine pancreas. Because CFTR is mainly expressed in ducts, the following section will consider pancreatic duct function on the cellular and integrated level. 
M. Wilschanski and I. Novak

\section{CFTR AND OTHER TRANSPORTERS IN PANCREATIC DUCT SECRETION- A CELLULAR APPROACH}

Pancreatic juice $\mathrm{HCO}_{3}{ }^{-}$concentrations vary with secretory rates, and they are inversed to changes in $\mathrm{Cl}^{-}$concentrations. Interestingly, the relation between secretory rates and $\mathrm{HCO}_{3}{ }^{-}$concentrations in pancreatic juice collected from the pancreas of various species fall within the same pattern (Fig. 2). This indicates that the basic mechanism of $\mathrm{HCO}_{3}{ }^{-}$secretion/salvaging may be similar (Fig. 3), but perhaps the duct mass is different. Taking this as a starting point, ion transport models based on studies of cells and tissues from various animals are suitable models for basic secretion mechanisms and for CF models.

\section{CFTR and Anion Exchanger}

The fingerprinting of cellular mechanisms for pancreatic duct ion transport began when it was discovered that secretin-/cAMP- activated $\mathrm{Cl}^{-}$ channels were functionally located on the luminal membranes of isolated rat pancreatic ducts, and the first ion transport models were proposed
(Gray et al. 1988; Novak and Greger 1988b). Almost at the same time, CFTR was discovered (Kerem et al. 1989; Riordan et al. 1989), and soon thereafter CFTR was shown to have properties of a $\mathrm{Cl}^{-}$channel, including in the pancreatic ducts (Gray et al. 1989, 1993; Tabcharani et al. 1991). Subsequently, CFTR was immunolocalized in rodent and human pancreas to intercalated and small intralobular ducts that also express aquaporins and carbonic ahydrases (Kumpulainen and Jalovaara 1981; Marino et al. 1991; Hyde et al. 1997; Burghardt et al. 2003).

The question of how CFTR $\mathrm{Cl}^{-}$channels could underlie $\mathrm{HCO}_{3}{ }^{-}$secretion of pancreas, has been a challenging problem ever since. The first proposal was that by coupling of $\mathrm{Cl}^{-}$ channels to $\mathrm{Cl}^{-} / \mathrm{HCO}_{3}{ }^{-}$exchange operating in parallel would result in efflux of $\mathrm{HCO}_{3}{ }^{-}$into the lumen. The anion exchangers belonging to the solute carrier families SLC26A6 and SLC26A3 were found expressed in pancreatic ducts, and the proposed transport ratio of $2 \mathrm{HCO}_{3}{ }^{-}: 1 \mathrm{Cl}^{-}$ for the first transporter would make it a candidate for secreting ducts (Lohi et al. 2000; Greeley et al. 2001; Dorwart et al. 2008). Until now, studies of SLC26A6 null mice showed

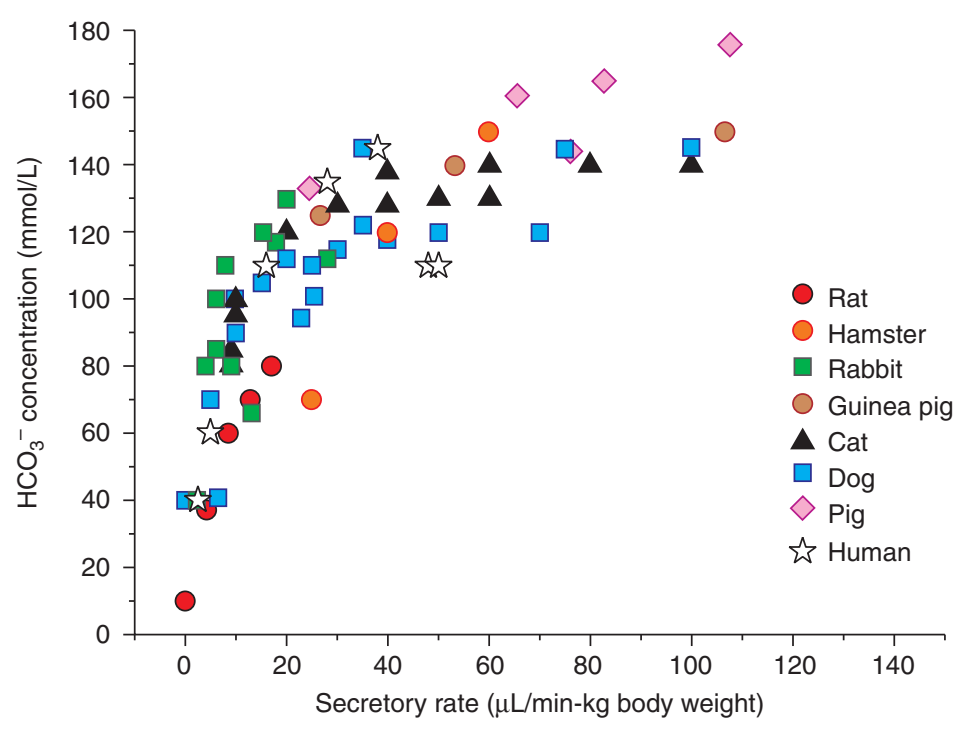

Figure 2. The relation between secretory rates and $\mathrm{HCO}_{3}{ }^{-}$concentrations in pancreatic juice of various species. Secretion was stimulated by secretin and secretory rate was collected for body weight. For details, see Novak et al. (2011). 


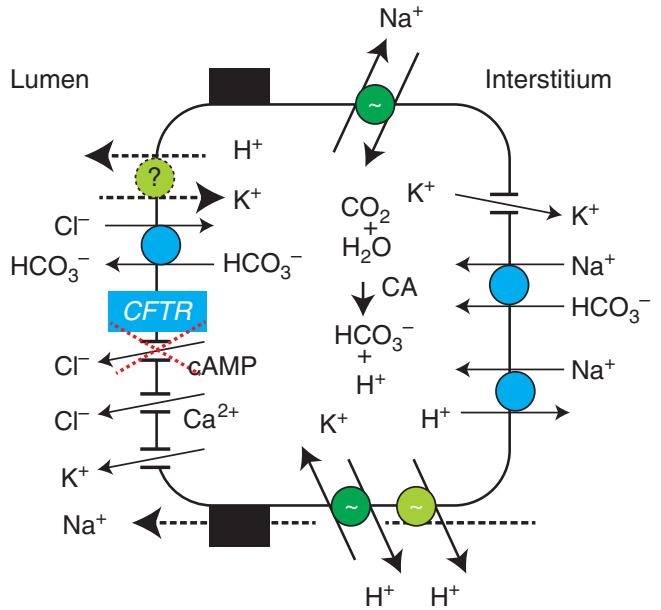

Figure 3. Cellular model for $\mathrm{HCO}_{3}^{-}$secretion in pancreatic ducts. Primary active transporters (pumps) and several secondary active transporters and ion channels, including $\mathrm{Ca}^{2+}$-activated $\mathrm{K}^{+}$and $\mathrm{Cl}^{-}$ channels, are involved in creating the chemical and electrical driving gradient necessary for production of $\mathrm{NaHCO}_{3}$-rich pancreatic juice in healthy pancreas, as described in text. The CFTR has central role pancreatic ducts; in $\mathrm{CF}$, pancreatic juice volume and $\mathrm{pH}$ are reduced.

different effects on duct/pancreas secretion (Wang et al. 2006; Ishiguro et al. 2007; Stewart et al. 2009; Yang et al. 2009). Nevertheless, it seems that there is a functional coupling between the R domain of CFTR and sulfate transporter anti-sigma (STAS) domains of this exchanger (Dorwart et al. 2008).

There are several studies that indicate other ways to achieve $\mathrm{HCO}_{3}^{-}$secretion. For example, the CFTR channel is $\mathrm{HCO}_{3}^{-}$permeable or CFTR regulates anion selectivity of another channel/transporter. Thus, guinea pig pancreatic ducts secrete fluid (and presumably $\mathrm{HCO}_{3}^{-}$) in the absence of luminal $\mathrm{Cl}^{-}$, in which $\mathrm{Cl}^{-} /$ $\mathrm{HCO}_{3}{ }^{-}$exchange would not favor $\mathrm{HCO}_{3}{ }^{-}$secretion (Ishiguro et al. 1998, 2009). Another study on HEK293 cells expression system showed that CFTR mutants associated with PI (e.g., I1489T) did not support $\mathrm{HCO}_{3}{ }^{-}$transport, whereas those associated with PS (e.g., R117H) show reduced transport (Choi et al. 2001). Indeed, many studies, also on pancreatic ducts, investigated whether CFTR conducts $\mathrm{HCO}_{3}^{-}$(Becq et al. 1993; Gray et al. 1993; O’Reilly et al. 2000). Until very recently, the consensus was that the permeability ratio $\mathrm{PHCO}_{3}{ }^{-} / \mathrm{PCl}^{-}$was $>0.2-$ 0.4 in conditions with intracellular $\mathrm{Cl}^{-}$and $\mathrm{pH}$ values expected for most epithelia. A newer study also shows similar permeability ratio and it remains independent of ionic conditions (Tang et al. 2009).

Nevertheless, a recent study shows that human and rodent tissues express volume $/ \mathrm{Cl}_{\mathrm{i}}^{-}$ sensitive WNK1 kinase and two downstream kinases, SPAK and OSR1. Using patch-clamp recording, it was reported that $P \mathrm{HCO}_{3}^{-} / \mathrm{PCl}^{-}$ increased from 0.24 to 1.09 when the $\mathrm{Cl}^{-}$concentration in the pipette was decreased from 150 to $4 \mathrm{mM}$, and investigators ascribed this permeability to CFTR. The investigators postulated that WNK1-OSR1/SPAK pathway is a molecular switch operating in distal ducts, which leads to increased concentration of incoming $\mathrm{HCO}_{3}{ }_{3}^{-}$ from 80 to $150 \mathrm{~mm}$ (Park et al. 2010). Although attractive, the model does not yet explain how increased concentration of $\mathrm{HCO}_{3}^{-}$would associate with fluid transport, and it cannot account for the fact that proximal small ducts are the richest sites of CFTR/AQP/carbonic anhydrase expression. Also, other studies show that WNKs inhibit CFTR (Yang et al. 2007, 2011). No doubt this exciting field of volume-sensitive kinases may not only be of relevance to kidney and blood pressure regulation, but also to salt and water transport in other epithelia.

\section{NHE and NBC}

In any case, $\mathrm{HCO}_{3}{ }^{-}$transport across the luminal membrane relies on provision of cellular $\mathrm{HCO}_{3}^{-}$. This source could be achieved by carbonic-anhydrase catalyzed hydration of $\mathrm{CO}_{2}$, and extrusion of resulting $\mathrm{H}^{+}$to the interstitium via a basolateral $\mathrm{Na}^{+} / \mathrm{H}^{+}$exchanger, NHE1. Alternatively, or in addition, $\mathrm{HCO}_{3}{ }^{-}$could enter across the basolateral membrane by pancreatic $\mathrm{Na}^{+}{ }_{-}$ $\mathrm{HCO}_{3}{ }^{-}$cotransporter, pNBC, which transports $1 \mathrm{Na}^{+}: 2 \mathrm{HCO}_{3}^{-}$(also named NBCe1) (Zhao et al. 1994; Ishiguro et al. 1996; Abuladze et al. 1998). Recent studies show that IRBIT (inositol-3-phosphate receptor-binding protein) activates $\mathrm{pNBC}$ and CFTR, and thus could be 
a coordinating factor for transepithelial ion transport (Shirakabe et al. 2006; Yang et al., 2009, 2011). Thus, $\mathrm{Ca}^{2+} / \mathrm{IP}_{3}$ activating agonists could regulate $\mathrm{HCO}_{3}^{-}$secretion, if the appropriate ion transporters on the luminal membrane are present (see below).

\section{Proton Pumps}

In addition to the secondary active transporters, NHE1 and pNBC, several earlier studies searched for primary active transporters (Fig. 3 ). One obvious candidate is the vacuolar $\mathrm{H}^{+}$. pump, but evidence at the molecular level is missing, and the function in stimulated ducts is unclear (Zhao et al. 1994; Villanger et al. 1995; de Ondarza and Hootman 1997; Cheng et al. 1998). Recently, another study focused on other types of pumps, and it was shown that rodent pancreatic ducts express both gastric and nongastric $\mathrm{H}^{+} / \mathrm{K}^{+}$pumps, which significantly contribute to secretin-stimulated duct secretion (Novak et al. 2011).

\section{Other Roles of CFTR}

CFTR can regulate other transporters including $\mathrm{Cl}^{-} / \mathrm{HCO}_{3}{ }^{-}$exchange in pancreatic tissue (Lee et al. 1999). In other respiratory epithelia, CFTR and $\mathrm{ENaC}$ are inversely regulated (Donaldson and Boucher 2007). Freshly isolated rodent duct and in vivo pancreas studies show no evidence for functional ENaC (Novak and Hansen 2002), although on culture, interlobular murine ducts develop sensitivity to amiloride and in some situations can even absorb (Zeiher et al. 1995; Pascua et al. 2009).

One important feature of epithelial secretion of CF patients is the high mucus content. This phenomenon may not be only a consequence of lack of hydration or increased number of mucus secreting cells. It is proposed that $\mathrm{HCO}_{3}{ }^{-}$is a chaotropic anion important in mucus expansion and, therefore, lack of CFTR function will impair mucus hydration (Quinton 2008; De Lisle 2009; Garcia et al. 2009; Chong et al. 2013). This may be of relevance to distal pancreatic ducts that contain numerous mucus secreting cells.
A number of studies on various cells indicate that CFTR is involved in release of ATP from intracellular to extracellular spaces, and CFTR has been ascribed the role of an ATP transporter or regulator. Currently, a number of other ATP release mechanisms are more favored (Novak 2011).

\section{$\mathrm{Ca}^{2+}$-Activated $\mathrm{Cl}^{-}$Channels}

In addition to CFTR, which is mainly regulated by cAMP/PKA signaling, $\mathrm{Ca}^{2+}$-activated $\mathrm{Cl}^{-}$ channels ( $\mathrm{CaCC}$ ) could potentially drive secretion (Fig. 3). In rodent and human pancreatic ducts, many studies have shown that a number of agonists increase cellular $\mathrm{Ca}^{2+}$, increase $\mathrm{Cl}^{-}$ conductance (although transiently), change $\mathrm{pH}_{\mathrm{i}}$, and evoke fluid production in isolated ducts (Pahl and Novak 1993; Hug et al. 1994; Winpenny et al. 1998; Szalmay et al. 2001; Pascua et al. 2009). The question is whether this secretion is also $\mathrm{HCO}_{3}{ }^{-}$rich, that is, if machinery similar to that operated by CFTR could be recruited, and/or if such $\mathrm{CaCC}$ are also $\mathrm{HCO}_{3}{ }^{-}$ permeable. If IRBIT stimulates pNBC (see above), $\mathrm{HCO}_{3}{ }^{-}$permeability on the luminal membrane would be required.

Interestingly, the identity of such CaCC has been elusive and a number of candidates were proposed earlier, including $\mathrm{ClC}-2$ and bestrophins (Duran et al. 2010). Recently, three independent reports have shown that the TMEM16/ Anoctamine families are good candidates for CaCC (Caputo et al. 2008; Schroeder et al. 2008; Yang et al. 2008). TMEM16A is expressed in rodent acinar cells (Yang et al. 2008) and knockout of TMEM16A in mice caused defects in $\mathrm{CaCC}$ in pancreatic acini (Ousingsawat et al. 2009). TMEM16A is also expressed in CFPAC1 cells (Caputo et al. 2008) and in human pancreatic duct cell lines expressing normal CFTR, in which it determines transepithelial transport (Wang et al. 2013).

\section{$\mathrm{K}^{+}$Channels}

$\mathrm{K}^{+}$channels are not usually included in pancreatic duct cell models. Nevertheless, there are two indications that $\mathrm{K}^{+}$transport is also important 
in pancreatic ducts. First of all, pancreatic juice contains $\mathrm{K}^{+}$higher than in plasma. The $\mathrm{K}^{+}$conductance is increased with several agonists, and it is clear that $\mathrm{K}^{+}$channels are not only important for setting the resting membrane potential, but they also keep the driving force for anion secretion (Novak and Greger 1988a, 1991). We know the identity of some $\mathrm{K}^{+}$channels; this includes BK (maxi-K, SLO, KCNMA1), IK (KCNN4), TASK-2 (KCNK5), and others. Some are located on both the luminal and basolateral membranes, which may be operated by different regulatory systems (Gray et al. 1990; Fong et al. 2003; Hede et al. 2005; Jung et al. 2006; Hayashi et al. 2012).

\section{Regulation of Pancreatic Duct Secretion}

The classical bicarbonate-evoking secretagogue is secretin, although a number of other hormones and transmitters can also evoke and coregulate $\left(\mathrm{HCO}_{3}{ }^{-}\right)$secretion. Even cholinergic stimulation and $\mathrm{CCK}$ can evoke $\mathrm{HCO}_{3}{ }^{-}$secretion in some species, and they can potentiate the secretin effect on the volume of secretion (You et al. 1983; Holst 1993; Park et al. 1998; Chey and Chang 2001), although there are exceptions (Evans et al. 1996). Whether human pancreatic juice is also rich in $\mathrm{HCO}_{3}{ }^{-}$under these conditions is not clear.

One of the novel additions to regulation of pancreatic fluid secretion is the purinergic signaling, which coordinates acini-duct functions. This pathway relies on extracellular ATP and adenosine that, via purinergic and adenosine receptors, regulates specific epithelial transporters (Novak 2008, 2011). Pancreatic acini release ATP, some of which is stored in zymogen granules (Sørensen and Novak 2001; Haanes and Novak 2010). Pancreatic ducts express several types of $\mathrm{P} 2$ receptors, including $\mathrm{P} 2 \mathrm{Y} 2, \mathrm{P} 2 \mathrm{Y} 4$, $\mathrm{P} 2 \mathrm{Y} 11, \mathrm{P} 2 \mathrm{X} 4$, and $\mathrm{P} 2 \mathrm{X} 7$ receptors, and adenosine A2A and A2B receptors. Luminal ATP can then upregulate anion and fluid secretion, and this activity involves regulation of $\mathrm{CaCC}$ and IK (Hug et al. 1994; Ishiguro et al. 1999; Hede et al. 2005; Jung et al. 2006; Novak et al. 2010; Hayashi et al. 2012; Wang et al. 2013). ATP also stimulates luminal anion exchange in duct epi- thelia expressing functional CFTR (Namkung et al. 2003). In addition, ATP/uridine triphosphate (UTP) also potentiate cAMP-evoked mucin secretion (Jung et al. 2010). From the basolateral membrane, ATP may be released by nerves and/or distended epithelium; some purinergic receptors are inhibitory to secretion (e.g., P2Y2 receptors inhibit BK channels) whereas other receptors may have positive effects on secretion (Hede et al. 1999, 2005; Ishiguro et al. 1999; Wang et al. 2013).

\section{ANIMAL MODELS FOR CF OF PANCREAS- INTEGRATED APPROACH}

Although physiological studies on isolated ducts and human duct cell lines have taught us much about ion transport and regulation thereof, it is not enough to understand the impact of CFTR mutations on whole gland pathophysiology in $\mathrm{CF}$. That is, we have to understand the link between dysfunction in $\mathrm{HCO}_{3}{ }^{-}$secretion, enzyme secretion, mucus plugging, and changes in pancreas morphology at an integrated level. Therefore, CF animal models have been invaluable, although challenging our understanding at times. The first mouse models of CF were developed shortly after the discovery of CFTR, and recently they were followed by very promising CF models in pigs and ferrets.

\section{Mouse CF Models}

There are a number of murine CF models developed, although a variety are gene-targeting strategies. These mice showed processing of mutated proteins, presence of other rescuing transporters, and last but not least, diversity in murine genetic background. These variables have led to heterogeneity of disease manifestations in mouse models (Ostedgaard et al. 2007). Generally, defects in airways and pancreas have been milder and more subtle to detect, whereas abnormalities in ion transport and morphology of intestinal tissues are marked and newborn mice suffer from intestinal obstruction. This is quite different from humans, in which only $10 \%$ of newborns have meconium ileus but 
already $80 \%-90 \%$ have PI. Thus, there is apparent discordance between intestinal and pancreatic CF phenotype in newborns. However, the rodent pancreas is different from the human pancreas in structure and development. The rodent pancreas is immature at birth and undergoes significant weight increase and maturation development postnatally, regarding enzyme and bicarbonate secretion (Githens 1994; Scaglia et al. 1997).

In the following section, we will focus on CF mouse models with respect to pancreas. The first CF mouse model was generated at the University of North Carolina and is denoted $\mathrm{CFTR}^{\mathrm{tm} 1 \mathrm{UNC}}$. Only $5 \%$ of animals survived, exhibiting severe intestinal problems, but the pancreas morphology was not markedly affected at the point of the initial examination (Snouwaert et al. 1992). In a similar knockout model generated in Cambridge, CFTR $^{\mathrm{tm} 1 \mathrm{CAM}}$, about $40 \%$ of animals survived and about half of the mice showed some pancreatic pathology (i.e., blockage of pancreatic ducts), possibly because these animals lived longer (Ratcliff et al. 1993). In the Baylor College model $\left(\mathrm{CFTR}^{\mathrm{tm} 1 \mathrm{BAY}}\right)$, newborn knockout animals had normal pancreas, but with increasing age, some animals showed dilatation and inflammation of main ducts as well as some acinar atrophy (O’Neal et al. 1993). In the Edinburgh model (CFTR $\left.{ }^{\mathrm{tm} 1 \mathrm{HGU}}\right)$, there remained $10 \%$ of wild-type CFTR mRNA, 95\% mice survived, and the phenotype was milder (Dorin et al. 1992, 1994).

As the reports above indicate, development of $\mathrm{CF}$ in murine pancreas may depend on time. If animals were put on a complete supplemented liquid diet, they were able to survive longer, develop manifestations of CF in many organs, including pancreas, such as duct lumen dilatation and obstruction and acinar atrophy (Durie et al. 2004). Knockout animals still had lower body weight, lower pancreas mass and pancreatic enzyme content. Possibly, this lower weight was not only caused by the CF defect, but was partly attributable to malnutrition (Ip et al. 1996).

First, we summarize what is known about the acinar-related pathology. Acini of CFTR ${ }^{\text {tmlUNC }}$ homozygous mice had fewer zymogen granules and the major sulfated glycoprotein, gp300, normally present in ZG, was lining distended acinar lumens. There was also impaired apical membrane trafficking compared to wild-type mice (De Lisle 1995, 2001). In isolated acini from knockout animals, there was enhanced secretory protein response with dibutyryl-cAMP (dbcAMP) and carbachol, which may contribute to micro-precipitation and development of acinar dysfunction (Tang et al. 1999). Increased levels of mRNA for secretin and VIP and pancreatic cAMP levels indicated that pancreas was chronically stimulated (De Lisle et al. 2001), and there was impaired stress-gene expression (Kaur et al. 2004). Also knockout animals had mild PI, higher baseline proinflammatory states, and an antiapoptotic phenotype, which may sensitize them to develop more severe acute pancreatitis with a marked pancreatic inflammatory response (DiMagno et al. 2005).

Second, let us examine whether knockout mice also showed signs of pancreatic ductal disorders. CFTR ${ }^{\text {tmlUNC }}$ knockout mice produced lower volume and acidic pancreatic-biliary juice after secretin stimulation, and there was also reduced response to CCK (Freedman et al. 2001; DiMagno et al. 2005). In cultured duct monolayer from CFTR ${ }^{\text {tm1UNC }}$ knockout mice, forskolin stimulated small short-circuit currents (Isc) compared to the wild type, but ionomycin stimulated currents that were $3 \times$ higher in knockout than in wild-type preparation, indicating that $\mathrm{CaCC}$ was up-regulated (Clarke et al. 1994). Pancreatic ducts isolated from another CFTR-null mouse $\left(\mathrm{CFTR}^{\mathrm{tm} 1 \mathrm{CAM}}\right)$ secreted $60 \%$ less fluid when stimulated with forskolin, and apparently about $30 \%$ less with secretin, although the secretin response was much lower even in wild-type mice. In the same preparation, carbachol also induced secretion, but to about the same extent in both wild-type and CFTRnull ducts, indicating that $\mathrm{CaCC}$ was well expressed and not up-regulated in knockouts (Pascua et al. 2009). Similar conclusions were reached using whole-cell patch-clamp on duct cells from the same mutant type. Ducts of knockout mice did not have any cAMP-activated currents (i.e., CFTR), but ionomycin-stimulated currents that were about $10 \times$ higher than 
CFTR-currents, and these are about the same in both wild-type and knockout cells (Winpenny et al. 1995). In CFTR ${ }^{\text {tm1HGU }}$ model, there is residual CFTR activity (10\% CFTR mRNA is expressed), but ionomycin-induced currents (i.e., CaCC) were larger and again similar in both wild-type and knockout cells (Gray et al. 1994). Thus, most studies show that $\mathrm{CaCC}$ was not up-regulated in $\mathrm{CFTR}^{-/-}$.

Nevertheless, the duct studies mentioned above leave some issues. First, the ducts used were short- and long-term cultured, and some endogenous receptors were down-regulated. Therefore, experiments necessitate use of agents that stimulate "simple" signaling pathways than one might expect for receptors. Second, all mouse studies are performed on larger ducts that would not be primary secretors and can even absorb (Zeiher et al. 1995; Pascua et al. 2009).

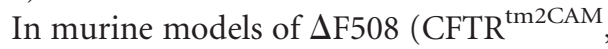
CFTR $^{\text {tm2KTH }^{2}}$, CFTR ${ }^{\text {tm1EUR }^{2}}$, there can be a gradient for severity of CFTR- $\Delta$ F508 processing defects that is more serious in humans than in mouse or pig (Ostedgaard et al. 2007). That is, $\Delta$ F508 CFTR is partially processed in mouse. Animals survive into adulthood and display several abnormalities seen in human $\Delta$ F508 patients. They also show little or no pancreatic histopathology (van Doorninck et al. 1995; Zeiher et al. 1995), although functional studies indicate some abnormalities. Cultured duct epithelium from $\mathrm{CFTR}^{\mathrm{tm} 2 \mathrm{KTH}}$ mice shows that a cAMP agonist can induce secretion and Isc changes in wild type but not in $\Delta$ F508. Thus, one could expect at least mild pancreas phenotype (Zeiher et al. 1995). Also, forskolin stimulated anion exchanger activity in luminal membranes of perfused main ducts was lower in mutants compared to wild type (Lee et al. 1999). In contrast, similar ducts express less NHE3, and CFTR interaction with NHE3 postulated in $\mathrm{HCO}_{3}^{-}$salvage mechanisms (Ahn et al. 2001) could affect anionic composition of juice. In humans, CFTR gene mutations associate with recurrent acute pancreatitis in patients with PS. Both $\mathrm{CFTR}^{-/-}$and $\Delta$ F508 mice develop caerulein-induced pancreatitis (DiMagno et al. 2005, 2010).
G551D and G480C mutants would be of interest for pancreas, as these mutations are associated with PI. However, mice with this mutation have milder symptoms compared to null mice (e.g., reduced risk of fatal intestinal blockage), and they have residual $(\sim 4 \%)$ mutant activity, and no pancreas and lung pathology was detected or studied (Delaney et al. 1996; Dickinson et al. 2002).

\section{Pig and Ferret CF Models}

Relatively mild changes in airway and pancreatic epithelia of mouse models spurred development of CF models in other animals. In contrast to mice, pigs have many physiological and anatomical features similar to humans. Recently, a pig model of CF was made by targeted disruption of both CFTR alleles. Newborn CFTR ${ }^{-/-}$ pigs exhibit many CF features, including exocrine pancreatic pathology (dilated and obstructed ducts with mucus incretion, residual acini, interstitial zymogen material, limited inflammation, and fibrosis (Rogers et al. 2008; Meyerholz et al. 2010). There were also intestinal lesions (meconium ileus and microcolon), and if surgically treated, animals reached developing lung abnormalities similar to CF patients. Also, degeneration of the pancreas continued, becoming more fatty, with markedly decreased exocrine cells, and obstructed ducts. Pig "cystic fibrosis of the pancreas" closely resembled Dorothy Anderson's original descriptions (Stoltz et al. 2010).

The ferret $\mathrm{CFTR}^{-/-}$model also has many characteristics of human CF disease including defective airway $\mathrm{Cl}^{-}$transport and submucosal gland secretion, pancreatic, liver, and vas deferens disease, and variable intestinal disorder (Sun et al. 2010). In the ferret, the pancreas of newborn animals showed dilated acini and ducts with inspissated eosinophilic zymogen secretions, but there was significantly less destruction as seen in newborn CF pigs.

Taken together, animal models are invaluable tools for studying basic and CF-related mechanisms of integrated pancreatic function, and the effects of therapeutics. Although pig and ferret models may develop CF more in line 
with humans, mouse models still offer a lot of potential especially in our understanding of regulation of cAMP versus $\mathrm{Ca}^{2+}$-driven anion secretion.

\section{THERAPEUTIC POTENTIALS FOR CF OF PANCREAS}

Therapeutic approaches for pancreatic treatments are very challenging, as most CF patients are born with PI or get it soon after, and the pancreatic mass is destroyed. In worst cases, when the liver is also affected, pancreas-liver transplantations are performed in a few centers. Another approach would be to reconstitute the pancreas mass using stem cell approaches. This would involve both acini and duct regeneration. At the moment, this task is not high on the research priority list in the CF field, perhaps because very good advances have been made with symptomatic strategies. The focus on treating PI patients is to provide sufficient nutrition, vitamins, and pancreatic enzyme replacement therapy to PI patients to improve nutritional status of the patient. Nevertheless, more progress is still needed, especially for lipase preparations, as enzymes do not work optimally in acidic duodenal environments. Therefore, there are special efforts to design improved lipase preparations by molecular design and recombinant technology (Colin et al. 2010). For example, recombinant acid-resistant lipase of plant origin Merispase (Meristem Therapeutics) is being evaluated in phase II trials. Another product in clinical trials contains microbial lipase, and also protease and amylase preparation ( $\mathrm{Li}-$ promatase, Lilly). These types of products may be essential as an alternative to porcine-based products.

In patients that still have some pancreas function (PS), the strategy must be to prevent duct/acini degradation, inflammation, and fibrosis, that is, development of pancreatitis. The problem is that PS patients have increased risk of pancreatitis. A number of anti-inflammatory and antioxidant agents are currently in use, including gluthathione, sildenafil, simavastatin, etc. However, further research and novel strategies are needed to improve the clinical care of
CF patients (Innis and Davidson 2008; Jones and Helm 2009).

Nevertheless, because the culprit is CFTR expressed in ducts, the main therapeutic strategies should be to modulate the basic defect here, which could possibly improve duct function in PI and PS patients and allow the pancreas to regenerate and develop. For CFTR protein rescue strategies, see Rowe and Verkman (2013).

Another approach is to bypass defective CFTR and activate CaCC (e.g., TMEM16A), although it is not clear whether the optimal target is the channel, intracellular $\mathrm{Ca}^{2+}$ levels, or a receptor regulating either or both (Cuthbert 2011). Activation of CaCC by the lantibiotic duramycin (Moli1901, Lancovutide, Lantibio) is being tested as a strategy and is in phase II trial in Europe. (The effect may be via raising intracellular calcium levels.) The outcome for pancreas is unclear, as tests on cell lines Panc-1 and CFPAC-1 indicate that the effects are nonspecific (Oliynyk et al. 2010). Also, studies on CF mouse models and human pancreatic cell lines indicate that $\mathrm{CaCC}$ does not take over from CFTR (see above). Another channel that may be relevant for some epithelia is $\mathrm{ClC}-2$ that is activated by lubiprostone, although the effect is via the prostanoid receptor EP4 (Cuthbert 2011), and $\mathrm{ClC}-2$ is only expressed in pancreatic acini.

An extension of this strategy would be to enhance natural regulator of $\mathrm{CaCC}$, such as $\mathrm{P} 2$ receptors (e.g., P2Y2 receptors), as has been envisaged for airways (Deterding et al. 2007; Lazarowski and Boucher 2009). Although the basic research and strategy was well planned, Denufasol tetrasodium (INS37217, Inspire) was taken out of phase III trials recently. For pancreas, one would need to target the receptors of the luminal membrane because the basolateral receptors can, in fact, inhibit secretion rather than stimulate it (see above). For obvious reasons, delivery of intraluminal UTP derivative is unrealistic.

\section{CONCLUDING REMARKS}

Translational research is identifying a number of compounds that offer promising pharmacotherapy for CF. However, regarding the pan- 
creas, therapeutic approaches are more complicated than for airways as they require systemic administration, and testing of pancreatic parameters in PS patients would need to be implemented. The possibility of increasing the function of a mutation that ordinarily confers PI to one that confers PS via a potentiator or corrector is appearing. However, this may result in increasing the risk of pancreatitis in a $\mathrm{CF}$ patient who did not suffer from this before. Before we move in this direction, we clearly need more drug studies on pancreatic function in good animal models.

\section{ACKNOWLEDGMENTS}

Work cited (I.N.) is supported by the Danish Natural Science Council and the Lundbeck Foundation.

\section{REFERENCES}

${ }^{*}$ Reference is also in this collection.

Abuladze N, Lee I, Newman D, Hwang J, Boorer K, Pushkin A, Kurtz I. 1998. Molecular cloning, chromosomal localization, tissue distribution, and functional expression of the human pancreatic sodium bicarbonate cotransporter. J Biol Chem 273: 17689-17695.

Ahn W, Kim KH, Lee JA, Kim JY, Choi JY, Moe OW, Milgram SL, Muallem S, Lee MG. 2001. Regulatory interaction between the cystic fibrosis transmembrane conductance regulator and. J Biol Chem 276: 1723617243.

Ainsworth MA, Ladegaard L, Svendsen P, Cantor P, Olsen O, Schaffalitzky de Muckadell OB. 1991. Pancreatic, hepatic, and duodenal mucosal bicarbonate secretion during infusion of secretin and cholecystokinin. Evidence of the importance of hepatic bicarbonate in the neutralization of acid in the duodenum of anaesthetized pigs. Scand J Gastroenterol 26: 1035-1041.

Barraclough M, Taylor CJ. 1996. Twenty-four hour ambulatory gastric and duodenal $\mathrm{pH}$ profiles in cystic fibrosis: Effect of duodenal hyperacidity on pancreatic enzyme function and fat absorption. J Ped Gastroenterol Nutr 23: 45-50.

Becq F, Hollande E, Gola M. 1993. Phosphorylation-regulated low-conductance $\mathrm{Cl}^{-}$channels in a human pancreatic duct cell line. Pflügers Arch 425: 1-8.

Behrendorff N, Floetenmeyer M, Schwiening C, Thorn P. 2010. Protons released during pancreatic acinar cell secretion acidify the lumen and contribute to pancreatitis in mice. Gastroenterology 139: 1711-1720.

Bishop MD, Freedman SD, Zielenski J, Ahmed N, Dupuis A, Martin S, Ellis L, Shea J, Hopper I, Corey M, et al. 2005. The cystic fibrosis transmembrane conductance regulator gene and ion channel function in patients with idiopathic pancreatitis. Hum Genet 118: 372-381.

Burghardt B, Elkaer ML, Kwon TH, Racz GZ, Varga G, Steward MC, Nielsen S. 2003. Distribution of aquaporin water channels AQP1 and AQP5 in the ductal system of the human pancreas. Gut 52: 1008-1016.

Caputo A, Caci E, Ferrera L, Pedemonte N, Barsanti C, Sondo E, Pfeffer U, Ravazzolo R, Zegarra-Moran O, Galietta LJ. 2008. TMEM16A, a membrane protein associated with calcium-dependent chloride channel activity. Science 322: 590-594.

Case RM, Argent BE. 1993. Pancreatic duct cell secretion. Control and mechanism of transport. In The pancreas biology, pathobiology, and disease (ed. Go VLW, et al.), pp. 301-350. Raven, New York.

Cheng HS, Leung PY, Cheng Chew SB, Leung PS, Lam SY, Wong WS, Wang ZD, Chan HC. 1998. Concurrent and independent $\mathrm{HCO}_{3}{ }^{-}$and $\mathrm{Cl}^{-}$secretion in a human pancreatic duct cell line (CAPAN-1). J Membr Biol 164: 155- 167.

Chey WY, Chang T. 2001. Neural hormonal regulation of exocrine pancreatic secretion. Pancreatology 1: 320-335.

Choi JY, Muallem D, Kiselyov K, Lee MG, Thomas PJ, Muallem S. 2001. Aberrant CFTR-dependent $\mathrm{HCO}_{3}{ }^{-}$ transport in mutations associated with cystic fibrosis. Nature 410: 94-97.

* Chong PA, Kota P, Dokholyan NV, Forman-Kay JD. 2013. Dynamics intrinsic to cystic fibrosis transmembrane conductance regulator function and stability. Cold Spring Harb Perspect Med. 3: a009522.

Clarke LL, Grubb BR, Yankaskas JR, Cotton CU, McKenzie A, Boucher RC. 1994. Relationship of a non-cystic fibrosis transmembrane conductance regulator-mediated chloride conductance to organ-level disease in $\mathrm{Cftr}^{-/-}$ mice. Proc Natl Acad Sci 91: 479-483.

Cohn JA, Friedman KJ, Noone PG, Knowles MR, Silverman LM, Jowell PS. 1998. Relation between mutations of the cystic fibrosis gene and idiopathic pancreatitis. $N$ Engl J Med 339: 653-658.

Colin DY, Prez-Beauclair P, Silva N, Infantes L, Kerfelec B. 2010. Modification of pancreatic lipase properties by directed molecular evolution. Protein Eng Des Sel 23: 365-373.

Cox KL, Isenberg JN, Ament ME. 1982. Gastric acid hypersecretion in cystic fibrosis. J Pediatr Gastroenterol Nutr 1: 559-565.

Cuthbert A. 2011. New horizons in the treatment of cystic fibrosis. Br J Pharmacol 163: 173-183.

De Boeck K, Weren M, Proesmans M, Kerem E. 2005. Pancreatitis among patients with cystic fibrosis: Correlation with pancreatic status and genotype. Pediatrics 115: e463-e469.

Delaney SJ, Alton EW, Smith SN, Lunn DP, Farley R, Lovelock PK, Thomson SA, Hume DA, Lamb D, Porteous DJ, et al. 1996. Cystic fibrosis mice carrying the missense mutation G551D replicate human genotype-phenotype correlations. EMBO J 15: 955-963.

De Lisle RC. 1995. Increased expression of sulfated gp300 and acinar tissue pathology in pancreas of $\mathrm{CFTR}^{-/-}$ mice. Am J Physiol 268: G717-G723. 
M. Wilschanski and I. Novak

De Lisle RC. 2009. Pass the bicarb: The importance of $\mathrm{HCO}_{3}^{-}$for mucin release. J Clin Invest 119: 2535-2537.

De Lisle RC, Isom KS, Ziemer D, Cotton CU. 2001. Changes in the exocrine pancreas secondary to altered small intestinal function in the CF mouse. Am J Physiol Gastrointest Liver Physiol 281: G899-G906.

de Ondarza J, Hootman SR. 1997. Confocal microscopic analysis of intracellular $\mathrm{pH}$ regulation in isolated guinea pig pancreatic ducts. Am J Physiol 272: G124-G134.

Deterding RR, LaVange LM, Engels JM, Mathews DW, Coquillette SJ, Brody AS, Millard SP, Ramsey BW. 2007. Phase 2 randomized safety and efficacy trial of nebulized denufosol tetrasodium in cystic fibrosis. Am J Respir Crit Care Med 176: 362-369.

Dickinson P, Smith SN, Webb S, Kilanowski FM, Campbell IJ, Taylor MS, Porteous DJ, Willemsen R, De Jonge HR, Farley R, et al. 2002. The severe G480C cystic fibrosis mutation, when replicated in the mouse, demonstrates mistrafficking, normal survival and organ-specific bioelectrics. Hum Mol Genet 11: 243-251.

DiMagno MJ, Lee SH, Hao Y, Zhou SY, McKenna BJ, Owyang C. 2005. A proinflammatory, antiapoptotic phenotype underlies the susceptibility to acute pancreatitis in cystic fibrosis transmembrane regulator $(-/-)$ mice. Gastroenterology 129: 665-681.

DiMagno MJ, Lee SH, Owyang C, Zhou SY. 2010. Inhibition of acinar apoptosis occurs during acute pancreatitis in the human homologue DeltaF508 cystic fibrosis mouse. Am J Physiol Gastrointest Liver Physiol 299: G400-G412.

Donaldson SH, Boucher RC. 2007. Sodium channels and cystic fibrosis. Chest 132: 1631-1636.

Dorin JR, Dickinson P, Emslie E, Clarke AR, Dobbie L, Hooper ML, Halford S, Wainwright BJ, Porteous DJ. 1992. Successful targeting of the mouse cystic fibrosis transmembrane conductance regulator gene in embryonal stem cells. Transgenic Res 1: 101-105.

Dorin JR, Stevenson BJ, Fleming S, Alton EW, Dickinson P, Porteous DJ. 1994. Long-term survival of the exon 10 insertional cystic fibrosis mutant mouse is a consequence of low level residual wild-type CFTR gene expression. Mamm Genome 5: 465-472.

Dorwart MR, Shcheynikov N, Yang D, Muallem S. 2008. The solute carrier 26 family of proteins in epithelial ion transport. Physiology 23: 104-114.

Duran C, Thompson CH, Xiao Q, Hartzell HC. 2010. Chloride channels: Often enigmatic, rarely predictable. Annu Rev Physiol 72: 95-121.

Durie PR, Kent G, Phillips MJ, Ackerley CA. 2004. Characteristic multiorgan pathology of cystic fibrosis in a longliving cystic fibrosis transmembrane regulator knockout murine model. Am J Pathol 164: 1481-1493.

Durno C, Corey M, Zielenski J, Tullis E, Tsui LC, Durie P. 2002. Genotype and phenotype correlations in patients with cystic fibrosis and pancreatitis. Gastroenterology 123: $1857-1864$.

Elgavish A. 1991. High intracellular pH in CFPAC: A pancreas cell line from a patient with cystic fibrosis is lowered by retrovirus-mediated CFTR gene transfer. Biochem Biophys Res Commun 180: $342-348$

Evans RL, Ashton N, Elliott AC, Green R, Argent BE. 1996. Interaction between secretin and acetylcholine in the reg- ulation of fluid secretion by isolated rat pancreatic ducts. J Physiol 461: 265-273.

Fong P, Argent BE, Guggino WB, Gray MA. 2003. Characterization of vectorial chloride transport pathways in the human pancreatic duct adenocarcinoma cell line, HPAF Am J Physiol Cell Physiol 285: C433-C445.

Freedman SD, Kern HF, Scheele G. 2001. Pancreatic acinar cell dysfunction in $\mathrm{CFTR}^{-/-}$mice is associated with impairments in luminal $\mathrm{pH}$ and endocytosis. Gastroenterology 121: 950-957.

Garcia MA, Yang N, Quinton PM. 2009. Normal mouse intestinal mucus release requires cystic fibrosis transmembrane regulator-dependent bicarbonate secretion. J Clin Invest 119: 2613-2622.

Githens S. 1994. Differentiation and development of the pancreas in animals. In The exocrine pancreas biology, pathology and diseases (ed. Go VLW, et al.), pp. 21-56. Raven, New York.

Gray MA, Greenwell JR, Argent BE. 1988. Secretin-regulated chloride channel on the apical plasma membrane of pancreatic duct cells. J Membr Biol 105: 131-142.

Gray MA, Harris A, Coleman L, Greenwell JR, Argent BE. 1989. Two types of chloride channel on duct cells cultured from human fetal pancreas. Am J Physiol 257: C240-C251.

Gray MA, Greenwell JR, Garton AJ, Argent BE. 1990. Regulation of maxi- $\mathrm{K}^{+}$channels on pancreatic duct cells by cyclic AMP-dependent phosphorylation. J Membr Biol 115: $203-215$.

Gray MA, Plant S, Argent BE. 1993. cAMP-regulated whole cell chloride currents in pancreatic duct cells. Am J Physiol Cell Physiol 264: C591-C602.

Gray MA, Winpenny JP, Porteous DJ, Dorin JR, Argent BE. 1994. CFTR and calcium-activated chloride currents in pancreatic duct cells of a transgenic CF mouse. Am J Physiol 266: C213-C221.

Greeley T, Shumaker H, Wang Z, Schweinfest CW, Soleimani M. 2001. Downregulated in adenoma and putative anion transporter are regulated by CFTR in cultured pancreatic duct cells. Am J Physiol Gastrointest Liver Physiol 281: G1301-G1308.

Haanes KA, Novak I. 2010. ATP storage and uptake by isolated pancreatic zymogen granules. Biochem J 429: 303-311.

Hayashi M, Wang J, Hede SE, Novak I. 2012. An intermediate-conductance $\mathrm{Ca}^{2+}$-activated $\mathrm{K}^{+}$channel is important for secretion in pancreatic duct cells. Am J Physiol Cell Physiol 303: C151-C159.

Hede SE, Amstrup J, Christoffersen BC, Novak I. 1999. Purinoceptors evoke different electrophysiological responses in pancreatic ducts. $\mathrm{P} 2 \mathrm{Y}$ inhibits $\mathrm{K}^{+}$conductance, and P2X stimulates cation conductance. J Biol Chem 274: 31784-31791.

Hede SE, Amstrup J, Klaerke DA, Novak I. 2005. P2Y 2 and $\mathrm{P}_{2} \mathrm{Y}_{4}$ receptors regulate pancreatic $\mathrm{Ca}^{2+}$ activated $\mathrm{K}^{+}$ channels differently. Pflügers Arch 450: 429-436.

Heitzmann D, Warth R. 2007. No potassium, no acid: $\mathrm{K}^{+}$ channels and gastric acid secretion. Physiology 22: 335341 .

Hirokawa M, Takeuchi T, Chu S, Akiba Y, Wu V, Guth PH, Engel E, Montrose MH, Kaunitz JD. 2004. Cystic fibrosis 
gene mutation reduces epithelial cell acidification and injury in acid-perfused mouse duodenum. Gastroenterology 127: 1162-1173.

Holst JJ. 1993. Neural regulation of pancreatic exocrine function. In The pancreas biology, pathobiology, and disease (ed. Go VLW, et al.), pp. 381-402. Raven, New York.

Hug M, Pahl C, Novak I. 1994. Effect of ATP, carbachol and other agonists on intracellular calcium activity and membrane voltage of pancreatic ducts. Pflügers Arch 426: 412-418.

Hyde K, Reid CJ, Tebbutt SJ, Weide L, Hollingsworth MA, Harris A. 1997. The cystic fibrosis transmembrane conductance regulator as a marker of human pancreatic duct development. Gastroenterology 113: 914-919.

Innis SM, Davidson AG. 2008. Cystic fibrosis and nutrition Linking phospholipids and essential fatty acids with thiol metabolism. Annu Rev Nutr 28: 55-72.

Ip WF, Bronsveld I, Kent G, Corey M, Durie PR. 1996. Exocrine pancreatic alterations in long-lived surviving cystic fibrosis mice. Pediatr Res 40: 242-249.

Ishiguro H, Steward MC, Lindsay ARG, Case RM. 1996 Accumulation of intracellular $\mathrm{HCO}_{3}^{-}$by $\mathrm{Na}^{+}-\mathrm{HCO}_{3}$ cotransport in interlobular ducts from guinea-pig pancreas. J Physiol 495: 169-178.

Ishiguro H, Naruse S, Steward MC, Kitagawa M, Ko SB Hayakawa T, Case RM. 1998. Fluid secretion in interlobular ducts isolated from guinea-pig pancreas. J Physiol 511: 407-422.

Ishiguro H, Naruse S, Kitagawa M, Hayakawa T, Case RM, Steward MC. 1999. Luminal ATP stimulates fluid and $\mathrm{HCO}_{3}^{-}$secretion in guinea-pig pancreatic duct. J Physiol 519: $551-558$.

Ishiguro H, Namkung W, Yamamoto A, Wang Z, Worrell RT, Xu J, Lee MG, Soleimani M. 2007. Effect of Slc26a6 deletion on apical $\mathrm{Cl}^{-} / \mathrm{HCO}_{3}{ }^{-}$exchanger activity and cAMPstimulated bicarbonate secretion in pancreatic duct. $A m$ J Physiol Gastrointest Liver Physiol 292: G447-G455.

Ishiguro H, Steward MC, Naruse S, Ko SB, Goto H, Case RM, Kondo T, Yamamoto A. 2009. CFTR functions as a bicarbonate channel in pancreatic duct cells. J Gen Physiol 133: $315-326$.

Jones AM, Helm JM. 2009. Emerging treatments in cystic fibrosis. Drugs 69: 1903-1910.

Jung SR, Kim K, Hille B, Nguyen TD, Koh DS. 2006. Pattern of $\mathrm{Ca}^{2+}$ increase determines the type of secretory mechanism activated in dog pancreatic duct epithelial cells. J Physiol 576: 163-178.

Jung SR, Hille B, Nguyen TD, Koh DS. 2010. Cyclic AMP potentiates $\mathrm{Ca}^{2+}$-dependent exocytosis in pancreatic duct epithelial cells. J Gen Physiol 135: 527-543.

Kaunitz JD, Akiba Y. 2006. Review article: Duodenal bicarbonate-mucosal protection, luminal chemosensing and acid-base balance. Aliment Pharmacol Ther 24: 169-176.

Kaur S, Norkina O, Ziemer D, Samuelson LC, De Lisle RC. 2004. Acidic duodenal $\mathrm{pH}$ alters gene expression in the cystic fibrosis mouse pancreas. Am J Physiol Gastrointest Liver Physiol 287: G480-G490.

Kerem B, Rommens JM, Buchanan JA, Markiewicz D, Cox TK, Chakravarti A, Buchwald M, Tsui LC. 1989. Identification of the cystic fibrosis gene: Genetic analysis. Science 245: 1073-1080.
Kerem E, Corey M, Kerem BS, Rommens J, Markiewicz D, Levison H, Tsui LC, Durie P. 1990. The relation between genotype and phenotype in cystic fibrosis-Analysis of the most common mutation (delta F508). N Engl J Med 323: $1517-1522$.

Kopelman H, Durie P, Gaskin K, Weizman Z, Forstner G. 1985. Pancreatic fluid secretion and protein hyperconcentration in cystic fibrosis. N Engl J Med 312: 329-334.

Kopelman H, Corey M, Gaskin K, Durie P, Weizman Z, Forstner G. 1988. Impaired chloride secretion, as well as bicarbonate secretion, underlies the fluid secretory defect in the cystic fibrosis pancreas. Gastroenterology 95: 349-355.

Kopic S, Geibel J. 2010. Update on the mechanisms of gastric acid secretion. Curr Gastroenterol Rep 12: 458-464.

Kristidis P, Bozon D, Corey M, Markiewicz D, Rommens J, Tsui LC, Durie P. 1992. Genetic determination of exocrine pancreatic function in cystic fibrosis. Am J Hum Genet 50: 1178-1184.

Kumpulainen T, Jalovaara P. 1981. Immunohistochemical localization of carbonic anhydrase isoenzymes in the human pancreas. Gastroenterology 80: 796-799.

Lazarowski ER, Boucher RC. 2009. Purinergic receptors in airway epithelia. Curr Opin Pharmacol 9: 262-267.

Lee MG, Choi JY, Luo X, Strickland E, Thomas PJ, Muallem S. 1999. Cystic fibrosis transmembrane conductance regulator regulates luminal $\mathrm{Cl}^{-} / \mathrm{HCO}_{3}^{-}$exchange in mouse submandibular and pancreatic ducts. $J$ Biol Chem 274: 14670-14677.

Lohi H, Kujala M, Kerkela E, Saarialho-Kere U, Kestila M, Kere J. 2000. Mapping of five new putative anion transporter genes in human and characterization of SLC26A6, a candidate gene for pancreatic anion exchanger. Genomics 70: 102-112.

Marino CR, Matovcik LM, Gorelick FS, Cohn JA. 1991. Localization of the cystic fibrosis transmembrane conductance regulator in pancreas. J Clin Invest 88: 712-716.

Meyerholz DK, Stoltz DA, Pezzulo AA, Welsh MJ. 2010. Pathology of gastrointestinal organs in a porcine model of cystic fibrosis. Am J Pathol 176: 1377-1389.

Namkung W, Lee JA, Ahn W, Han W, Kwon SW, Ahn DS, Kim KH, Lee MG. 2003. $\mathrm{Ca}^{2+}$ activates cystic fibrosis transmembrane conductance regulator- and $\mathrm{Cl}^{-}$-dependent $\mathrm{HCO}_{3}$ transport in pancreatic duct cells. J Biol Chem 278: $200-207$.

Novak I. 2008. Purinergic receptors in the endocrine and exocrine pancreas. Purinergic Signal 4: 237-253.

Novak I. 2011. Purinergic signalling in epithelial ion transport-regulation of secretion and absorption. Acta Physiol (Oxf) 202: 501-522.

Novak I, Greger R. 1988a. Electrophysiological study of transport systems in isolated perfused pancreatic ducts: Properties of the basolateral membrane. Pflügers Arch 411: 58-68.

Novak I, Greger R. 1988b. Properties of the luminal membrane of isolated perfused rat pancreatic ducts: Effect of cyclic AMP and blockers of chloride transport. Pflügers Arch 411: 546-553.

Novak I, Greger R. 1991. Effect of bicarbonate on potassium conductance of isolated perfused rat pancreatic ducts. Pflügers Arch 419: 76-83. 
M. Wilschanski and I. Novak

Novak I, Hansen MR. 2002. Where have all the $\mathrm{Na}^{+}$channels gone? In search of functional $\mathrm{ENaC}$ in exocrine pancreas. Biochim Biophys Acta 1566: 162-168.

Novak I, Jans IM, Wohlfahrt L. 2010. Effect of P2X7 receptor knockout on exocrine secretion of pancreas, salivary glands and lacrimal glands. J Physiol 588: 3615-3627.

Novak I, Wang J, Henriksen KL, Haanes KA, Krabbe S, Nitschke R, Hede SE. 2011. Pancreatic bicarbonate secretion involves two proton pumps. J Biol Chem 286: 280289.

Oliynyk I, Varelogianni G, Roomans GM, Johannesson M. 2010. Effect of duramycin on chloride transport and intracellular calcium concentration in cystic fibrosis and non-cystic fibrosis epithelia. APMIS 118: 982-990.

O’Neal WK, Hasty P, McCray PB Jr, Casey B, Rivera-Perez J, Welsh MJ, Beaudet AL, Bradley A. 1993. A severe phenotype in mice with a duplication of exon 3 in the cystic fibrosis locus. Hum Mol Genet 2: 1561-1569.

Ooi CY, Dorfman R, Cipolli M, Gonska T, Castellani C, Keenan K, Freedman SD, Zielenski J, Berthiaume Y, Corey M, et al. 2011. Type of CFTR mutation determines risk of pancreatitis in patients with cystic fibrosis. Gastroenterology 140: 153-161.

O’Reilly CM, Winpenny JP, Argent BE, Gray MA. 2000 Cystic fibrosis transmembrane conductance regulator currents in guinea pig pancreatic duct cells: Inhibition by bicarbonate ions. Gastroenterology 118: 1187-1196.

Ostedgaard LS, Rogers CS, Dong Q, Randak CO, Vermeer DW, Rokhlina T, Karp PH, Welsh MJ. 2007. Processing and function of CFTR-DeltaF508 are species-dependent. Proc Natl Acad Sci 104: 15370-15375.

Ousingsawat J, Martins JR, Schreiber R, Rock JR, Harfe BD, Kunzelmann K. 2009. Loss of TMEM16A causes a defect in epithelial $\mathrm{Ca}^{2+}$-dependent chloride transport. J Biol Chem 284: 28698-28703.

Pahl C, Novak I. 1993. Effect of vasoactive intestinal peptide, carbachol and other agonists on cell membrane voltage of pancreatic duct cells. Pflügers Arch 424: 315-320.

Park HS, Lee YL, Kwon HY, Chey WY, Park HJ. 1998. Significant cholinergic role in secretin-stimulated exocrine secretion in isolated rat pancreas. Am J Physiol 274: G413-G418.

Park HW, Nam JH, Kim JY, Namkung W, Yoon JS, Lee JS, Kim KS, Venglovecz V, Gray MA, Kim KH, et al. 2010. Dynamic regulation of CFTR bicarbonate permeability by $\mathrm{Cl}_{\mathrm{i}}{ }^{-}$and its role in pancreatic bicarbonate secretion. Gastroenterology 139: 620-631.

Pascua P, Garcia M, Fernandez-Salazar MP, HernandezLorenzo MP, Calvo JJ, Colledge WH, Case RM, Steward MC, San Roman JI. 2009. Ducts isolated from the pancreas of CFTR-null mice secrete fluid. Pflugers Arch 459: 203-214.

Proesmans M, De Boeck K. 2003. Omeprazole, a proton pump inhibitor, improves residual steatorrhoea in cystic fibrosis patients treated with high dose pancreatic enzymes. Eur J Pediatr 162: 760-763.

Quinton PM. 2008. Cystic fibrosis: Impaired bicarbonate secretion and mucoviscidosis. Lancet 372: 415-417.

Ratcliff R, Evans MJ, Cuthbert AW, MacVinish LJ, Foster D, Anderson JR, Colledge WH. 1993. Production of a severe cystic fibrosis mutation in mice by gene targeting. Nat Genet 4: 35-41.

Riordan JR, Rommens JM, Kerem B, Alon N, Rozmahel R, Grzelczak Z, Zielenski J, Lok S, Plavsic N, Chou JL. 1989. Identification of the cystic fibrosis gene: Cloning and characterization of complementary DNA. Science 245: 1066-1073.

Robinson PJ, Smith AL, Sly PD. 1990. Duodenal pH in cystic fibrosis and its relationship to fat malabsorption. Dig Dis Sci 35: 1299-1304.

Rogers CS, Stoltz DA, Meyerholz DK, Ostedgaard LS, Rokhlina T, Taft PJ, Rogan MP, Pezzulo AA, Karp PH, Itani OA, et al. 2008. Disruption of the CFTR gene produces a model of cystic fibrosis in newborn pigs. Science 321: $1837-1841$

* Rowe SM, Verkman AS. 2013. Cystic fibrosis transmembrane regulator correctors and potentiators. Cold Spring Harb Perspect Med doi: 10.1101/cshperspect.a009761.

Scaglia L, Cahill CJ, Finegood DT, Bonner-Weir S. 1997. Apoptosis participates in the remodeling of the endocrine pancreas in the neonatal rat. Endocrinology 138: 1736-1741.

Schneider A, Larusch J, Sun X, Aloe A, Lamb J, Hawes R, Cotton P, Brand RE, Anderson MA, Money ME, et al. 2011. Combined bicarbonate conductance-impairing variants in CFTR and SPINK1 variants are associated with chronic pancreatitis in patients without cystic fibrosis. Gastroenterology 140: 162-171.

Schroeder BC, Cheng T, Jan YN, Jan LY. 2008. Expression cloning of TMEM16A as a calcium-activated chloride channel subunit. Cell 134: 1019-1029.

Sewell WA, Young JA. 1975. Secretion of electrolytes by the pancreas of the anaesthetized rat. J Physiol 252: 379-396.

Sharer N, Schwarz M, Malone G, Howarth A, Painter J, Super M, Braganza J. 1998. Mutations of the cystic fibrosis gene in patients with chronic pancreatitis. $N$ Engl J Med 339: 645-652.

Shirakabe K, Priori G, Yamada H, Ando H, Horita S, Fujita T, Fujimoto I, Mizutani A, Seki G, Mikoshiba K. 2006. IRBIT, an inositol 1,4,5-trisphosphate receptorbinding protein, specifically binds to and activates pancreas-type $\mathrm{Na}^{+} / \mathrm{HCO}_{3}{ }^{-}$cotransporter 1 (pNBC1). Proc Natl Acad Sci 103: 9542-9547.

Shwachman H, Lebenthal E, Khaw KT. 1975. Recurrent acute pancreatitis in patients with cystic fibrosis with normal pancreatic enzymes. Pediatrics 55: 86-95.

Sidani SM, Kirchhoff P, Socrates T, Stelter L, Ferreira E, Caputo C, Roberts KE, Bell RL, Egan ME, Geibel JP. 2007. Delta F508 mutation results in impaired gastric acid secretion. J Biol Chem 282: 6068-6074.

Snouwaert JN, Brigman KK, Latour AM, Malouf NN, Boucher RC, Smithies O, Koller BH. 1992. An animal model for cystic fibrosis made by gene targeting. Science 257: $1083-1088$.

Sørensen CE, Novak I. 2001. Visualization of ATP release in pancreatic acini in response to cholinergic stimulus. Use of fluorescent probes and confocal microscopy. J Biol Chem 276: 32925-32932.

Stewart AK, Yamamoto A, Nakakuki M, Kondo T, Alper SL, Ishiguro H. 2009. Functional coupling of apical $\mathrm{Cl}^{-}$/ $\mathrm{HCO}_{3}^{-}$exchange with CFTR in stimulated $\mathrm{HCO}_{3}^{-}$ 
secretion by guinea pig interlobular pancreatic duct. $A m J$ Physiol Gastrointest Liver Physiol 296: G1307-G1317.

Stoltz DA, Meyerholz DK, Pezzulo AA, Ramachandran S, Rogan MP, Davis GJ, Hanfland RA, Wohlford-Lenane C, Dohrn CL, Bartlett JA, et al. 2010. Cystic fibrosis pigs develop lung disease and exhibit defective bacterial eradication at birth. Sci Transl Med 2: 29ra31.

Sun X, Sui H, Fisher JT, Yan Z, Liu X, Cho HJ, Joo NS, Zhang Y, Zhou W, Yi Y, et al. 2010. Disease phenotype of a ferret CFTR-knockout model of cystic fibrosis. J Clin Invest 120: 3149-3160.

Szalmay G, Varga G, Kajiyama F, Yang XS, Lang TF, Case RM, Steward MC. 2001. Bicarbonate and fluid secretion evoked by cholecystokinin, bombesin and acetylcholine in isolated guinea-pig pancreatic ducts. J Physiol 535: 795-807.

Tabcharani JA, Chang X-B, Riordan JR, Hanrahan JW. 1991. Phosphorylation-regulated $\mathrm{Cl}^{-}$channel in $\mathrm{CHO}$ cells stably expressing the cystic fibrosis gene. Nature 352: $628-631$.

Tang S, Beharry S, Kent G, Durie PR. 1999. Synergistic effects of cAMP- and calcium-mediated amylase secretion in isolated pancreatic acini from cystic fibrosis mice. $\mathrm{Pe}$ diatr Res 45: 482-488.

Tang L, Fatehi M, Linsdell P. 2009. Mechanism of direct bicarbonate transport by the CFTR anion channel. $J$ Cyst Fibros 8: 115-121.

Uc A, Stoltz DA, Ludwig P, Pezzulo A, Griffin M, bu-ElHaija M, bu-El-Haija M, Meyerholz DK, Taft P, Welsh MJ. 2011. Pancreatic and biliary secretion differ in cystic fibrosis and wild-type pigs. J Cyst Fibros 10: S69.

van Doorninck JH, French PJ, Verbeek E, Peters RH, Morreau H, Bijman J, Scholte BJ. 1995. A mouse model for the cystic fibrosis delta F508 mutation. EMBO J 14: 4403-4411.

Villanger O, Veel T, Ræder MG. 1995. Secretin causes $\mathrm{H}^{+} /$ $\mathrm{HCO}_{3}^{-}$secretion from pig pancreatic ductules by vacuolar-type $\mathrm{H}^{+}$-adenosine triphosphatase. Gastroenterology 108: $850-859$.

Wang Y, Soyombo AA, Shcheynikov N, Zeng W, Dorwart M, Marino CR, Thomas PJ, Muallem S. 2006. Slc26a6 regulates CFTR activity in vivo to determine pancreatic duct $\mathrm{HCO}_{3}{ }^{-}$secretion: Relevance to cystic fibrosis. EMBO J 25: 5049-5057.

Wang J, Haanes KA, Novak I. 2013. Purinergic regulation of CFTR and $\mathrm{Ca}^{2+}$-activated $\mathrm{Cl}^{-}$channels and $\mathrm{K}^{+}$channels in human pancreatic duct epithelium. Am J Physiol Cell Physiol 304: C673-C684.
Wilschanski M, Durie PR. 2007. Patterns of GI disease in adulthood associated with mutations in the CFTR gene. Gut 56: 1153-1163.

Wilschanski M, Dupuis A, Ellis L, Jarvi K, Zielenski J, Tullis E, Martin S, Corey M, Tsui LC, Durie P. 2006. Mutations in the cystic fibrosis transmembrane regulator gene and in vivo transepithelial potentials. Am J Respir Crit Care Med 174: 787-794.

Windstetter D, Schaefer F, Scharer K, Reiter K, Eife R, Harms HK, Bertele-Harms R, Fiedler F, Tsui LC, Reitmeir P, et al. 1997. Renal function and renotropic effects of secretin in cystic fibrosis. Eur J Med Res 2: 431-436.

Winpenny JP, Verdon B, McAlroy HL, Colledge WH, Ratcliff R, Evans MJ, Gray MA, Argent BE. 1995. Calcium-activated chloride conductance is not increased in pancreatic duct cells of CF mice. Pflügers Arch 430: 26-33.

Winpenny JP, Harris A, Hollingsworth MA, Argent BE, Gray MA. 1998. Calcium-activated chloride conductance in a pancreatic adenocarcinoma cell line of ductal origin (HPAF) and in freshly isolated human pancreatic duct cells. Pflugers Arch 435: 796-803.

Yang CL, Liu X, Paliege A, Zhu X, Bachmann S, Dawson DC, Ellison DH. 2007. WNK1 and WNK4 modulate CFTR activity. Biochem Biophys Res Commun 353: 535-540.

Yang YD, Cho H, Koo JY, Tak MH, Cho Y, Shim WS, Park SP, Lee J, Lee B, Kim BM, et al. 2008. TMEM16A confers receptor-activated calcium-dependent chloride conductance. Nature 455: 1210-1215.

Yang D, Shcheynikov N, Zeng W, Ohana E, So I, Ando H, Mizutani A, Mikoshiba K, Muallem S. 2009. IRBIT coordinates epithelial fluid and $\mathrm{HCO}_{3}^{-}$secretion by stimulating the transporters $\mathrm{pNBC} 1$ and $\mathrm{CFTR}$ in the murine pancreatic duct. J Clin Invest 119: 193-202.

Yang D, Li Q, So I, Huang CL, Ando H, Mizutani A, Seki G, Mikoshiba K, Thomas PJ, Muallem S. 2011. IRBIT governs epithelial secretion in mice by antagonizing the WNK/SPAK kinase pathway. JClin Invest 121: 956-965.

You CH, Rominger JM, Chey WY. 1983. Potentiation effect of cholecystokinin-octapeptide on pancreatic bicarbonate secretion stimulated by a physiologic dose of secretin in humans. Gastroenterology 85: 40-45.

Zeiher BG, Eichwald E, Zabner J, Smith JJ, Puga AP, McCray PB Jr, Capecchi MR, Welsh MJ, Thomas KR. 1995. A mouse model for the $\Delta \mathrm{F} 508$ allele of cystic fibrosis. J Clin Invest 96: 2051-2064.

Zhao H, Star RA, Muallem S. 1994. Membrane localization of $\mathrm{H}^{+}$and $\mathrm{HCO}_{3}^{-}$transporters in the rat pancreatic ducts. J Gen Physiol 104: 57-85. 


\section{$\&_{\mathrm{CSH}}^{\infty} \&$ Cold Spring Harbor

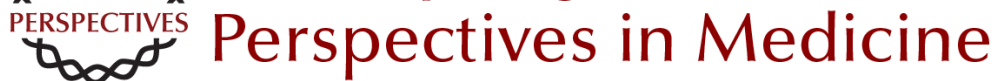

\section{The Cystic Fibrosis of Exocrine Pancreas}

Michael Wilschanski and Ivana Novak

Cold Spring Harb Perspect Med 2013; doi: 10.1101/cshperspect.a009746

Subject Collection Cystic Fibrosis

Antibiotic and Anti-Inflammatory Therapies for

Cystic Fibrosis

James F. Chmiel, Michael W. Konstan and J. Stuart Elborn

Structure and Function of the Mucus Clearance System of the Lung

Brenda M. Button and Brian Button

New Pulmonary Therapies Directed at Targets

Other than CFTR

Scott H. Donaldson and Luis Galietta

The Cystic Fibrosis Airway Microbiome

Susan V. Lynch and Kenneth D. Bruce

\section{Cystic Fibrosis Transmembrane Conductance \\ Regulator (ABCC7) Structure \\ John F. Hunt, Chi Wang and Robert C. Ford}

Status of Fluid and Electrolyte Absorption in

Cystic Fibrosis

M.M. Reddy and M. Jackson Stutts

The Influence of Genetics on Cystic Fibrosis

Phenotypes

Michael R. Knowles and Mitchell Drumm

Perspectives on Mucus Properties and Formation

--Lessons from the Biochemical World

Daniel Ambort, Malin E.V. Johansson, Jenny K.

Gustafsson, et al.
The Cystic Fibrosis Intestine

Robert C. De Lisle and Drucy Borowitz

Cystic Fibrosis Transmembrane Regulator

Correctors and Potentiators

Steven M. Rowe and Alan S. Verkman

The Cystic Fibrosis of Exocrine Pancreas

Michael Wilschanski and Ivana Novak

Dynamics Intrinsic to Cystic Fibrosis Transmembrane Conductance Regulator Function and Stability

P. Andrew Chong, Pradeep Kota, Nikolay V.

Dokholyan, et al.

The Cystic Fibrosis Gene: A Molecular Genetic

Perspective

Lap-Chee Tsui and Ruslan Dorfman

The CFTR Ion Channel: Gating, Regulation, and

Anion Permeation

Tzyh-Chang Hwang and Kevin L. Kirk

Assessing the Disease-Liability of Mutations in CFTR

Claude Ferec and Garry R. Cutting

Supramolecular Dynamics of Mucus Pedro Verdugo

For additional articles in this collection, see http://perspectivesinmedicine.cshlp.org/cgi/collection/ 